Purdue University Purdue e-Pubs

6-29-2012

\title{
Who Teaches Information Literacy Competencies? Report of a Study of Faculty
}

Sharon A. Weiner

sweiner@purdue.edu

Follow this and additional works at: http://docs.lib.purdue.edu/lib_fsdocs

Part of the Curriculum and Instruction Commons, Higher Education Commons, and the Information Literacy Commons

\section{Recommended Citation}

Weiner, Sharon A., "Who Teaches Information Literacy Competencies? Report of a Study of Faculty" (2012). Libraries Faculty and Staff Scholarship and Research. Paper 59.

http://dx.doi.org/10.1080/87567555.2013.803949

This document has been made available through Purdue e-Pubs, a service of the Purdue University Libraries. Please contact epubs@purdue.edu for additional information. 
Information Literacy

\section{Who Teaches Information Literacy Competencies?}

Report of a Study of Faculty

Sharon A. Weiner, EdD

Professor and W. Wayne Booker Chair in Information Literacy

Purdue University

Libraries

504 West State Street

West Lafayette, IN 47906

sweiner@purdue.edu 


\begin{abstract}
.
Information literacy is recognized as an essential competency for educational success. It relates to all disciplines but is not a separate discipline, so it is not clear who takes responsibility for teaching this competency to undergraduates. This is a report of a survey conducted to better understand the extent to which teaching information literacy concepts by faculty occurred in a research university. The results indicated that faculty in the disciplines generally teach information literacy competencies to undergraduate students without collaborating with others on their campus. Many faculty also had the expectation that students know how to avoid plagiarism, find articles and books, and define topics for their projects before students take their courses. There were disciplinary differences in providing instruction in critical evaluation and avoiding plagiarism. Tenured faculty tended to provide instruction in defining a topic; finding articles and books; and synthesizing information. Non-tenured faculty tended to teach students to avoid plagiarism.
\end{abstract}

Keywords: information literacy; curriculum; faculty; undergraduate students; collaboration 


\section{INTRODUCTION.}

Information literacy is recognized globally as an essential competency that has been linked to educational success; workplace readiness; lifelong learning; an informed citizenry; and a competitive workforce (S. Weiner 2011, p. 302). A commonly-used definition of information literacy is the ability to:

1. Determine the nature and extent of information needed

2. Access the needed information effectively and efficiently

3. Evaluate information and its sources critically

4. Use information effectively to accomplish a specific purpose

5. Understand the economic, legal, and social issues surrounding the use of information

6. Access and use information ethically and legally (ACRL, 2000)

There is evidence that faculty consider information literacy to be important for undergraduate students to develop (Willison 2012, 11; Wu and Kendall 2006, p. 92; McGuinness 2006; Gullikson 2006, p. 588). Information literacy is related to critical thinking (J. Weiner 2011, p. 89); digital, media, health, and other literacies (Garner 2006, p. 5). Many postsecondary educational institutions include information literacy as an expected learning outcome for students (College Learning 2007, p. 3; Saunders 2007). Information literacy is becoming an integral part of institutional planning: $33 \%$ of college and universities in the U.S. incorporated information literacy into their institutional mission statements in 2010 (Supplemental Academic 2010, Table 13).

Ideally, learning and practicing information literacy competencies occurs throughout a curriculum, building progressively throughout an academic program so that students have a disciplinary context for developing the competencies (Wang 2011; Breivik 2004, p. xiii). The 
practice of information literacy is different, depending on the context or discipline (Walter 2007, p. 562-64).

\section{Information Literacy Expectations of Undergraduates.}

The National Survey of Student Engagement (NSSE) collects data "about student participation in programs and activities that institutions provide for their learning and personal development" (About NSSE 2012). NSSE includes questions about course expectations for firstyear and senior students that are related to information literacy. Mark and Boruff-Jones mapped questions from the 2001 NSSE Survey to the ACRL Standards and Bloom's Taxonomy (2003 p. 485-90). This author found that at least ten of the questions on the 2009-2010 National Survey of Student Engagement (NSSE) were related to information literacy. Table 1 shows those questions and the information literacy standards to which they map.

\section{[Insert Table 1]}

The results of the 2010 administration of the survey showed that students needed to demonstrate information literacy competencies during their undergraduate coursework. Table 2 shows the percentage of first-year and senior students nationally, from institutions with very high research activity and from Purdue University, whose coursework included any of the information literacy competencies as mapped to the survey questions above.

[Insert Table 2]

\section{Responsibility for Teaching Information Literacy Competencies.}

Since information literacy is not a discipline by itself, but is relevant in all disciplines, those individuals or groups responsible for integrating it into courses and curricula may not be apparent or even designated. There are many reports of collaborations on teaching information literacy competencies between faculty in the disciplines and others on campus, particularly librarians (Bury 2011; Johnson, Whitfield, and Grohe 2011; Allner 2010; Dobozy and Gorss 
2010; Kobzina 2010; Barratt 2009; Dugan 2008; Caravello 2008; Madray 2008; Floyd, Colvin, and Bodur 2008; Elrod and Somerville 2007). Because of the extensive work done to operationalize and promote information literacy by organizations such as the Association of College and Research Libraries, academic librarians teach information literacy competencies through credit-bearing courses, guest-lectures in courses or co-curricular learning activities, participating as "embedded" librarians on problem-based learning or course project teams, and consulting with students and faculty individually. Information literacy programs are formal departments in academic libraries that hire specialists to develop teaching resources and collaborate with faculty.

There are few studies of faculty to learn what they are teaching in relation to information literacy (Bury 2011; Garritano and Culp 2010; McGuinness 2006). Faculty at York University in Canada thought that information literacy should be taught collaboratively between librarians and faculty (Bury 2011, p. 53). However, faculty who participated in a study of their perceptions of information literacy believed that it was the individual student's responsibility to develop information literacy competencies. They did not think that formal instruction was necessary because they thought that information literacy was intuitive or could be learned from peers (McGuinness 2006, p. 575, 578-9).

\section{Assessment of Information Literacy.}

There is no uniformly accepted way to assess information literacy for accreditation agencies, strategic plan progress reports, and other reporting purposes. Instruments such as iSkills $^{\mathrm{TM}}$ (http://www.ets.org/iskills/about), SAILS, (https://www.projectsails.org/) or locallydeveloped assessments can measure whether a student or cohort of students have competency 
with selected aspects of information literacy. However, these instruments are limited in what they measure and the cost of instruments can be a deterrent to large-scale administration.

Information literacy at the institutional level is commonly measured by the National Center for Education Statistics, the Association of Research Libraries, and the Association of College and Research Libraries by the number of presentations that librarians give to students and the number of students who attend those. This measure is limited because it does not include teaching of information literacy done by others on a campus; and it does not indicate what students actually learn. The perspective of the faculty on what they teach in relation to information literacy is important because faculty have primary responsibility for the teaching of undergraduate students. An understanding of what they are teaching or not teaching in relation to information literacy in their courses would be helpful in identifying gaps in curricula and ensuring that students have exposure to information literacy concepts at optimal points in their courses of studies. It would also be helpful to understand what faculty expect students to know in relation to information literacy as a pre-requisite to taking their courses.

The purpose of this report is to better understand the extent to which teaching information literacy concepts to undergraduate students occurred at one large research university. This understanding will provide important information for those responsible for assessment, for curricula, and for information literacy programs.

\section{METHODS.}

Purdue University is a state-assisted research and land grant university in the Midwest with around 40,000 students and 2,500 faculty. These Colleges and Schools comprise the academic units: Agriculture; Education; Engineering; Health and Human Sciences; Liberal Arts; 
Information Literacy

Management; Pharmacy; Science; Technology; and Veterinary Medicine. The investigator developed a 10-item survey (see Appendix 1) based on the Information Literacy Competency Standards for Higher Education (ACRL). These standards are related to Bloom's Taxonomy (Bloom 1956) and have been the model for the development of information literacy standards internationally (SCONUL 2011; Irving and Crawford 2008; Bundy 2004). The survey was sent to 2,554 faculty email addresses in Spring 2011.

\section{RESULTS.}

Several faculty from the College of Pharmacy and the School of Veterinary Medicine raised questions immediately after the survey distribution about their eligibility to participate They explained that students in those areas were professional students, not undergraduates, although many did not have bachelors degrees. Because of this confusion, data from those programs were excluded from the analysis.

\section{Response Rate.}

The overall response rate for the University was $12 \%(n=299)$ and the median was $13 \%$. The response rate for the Colleges/Schools varied from less than $10 \%$ for the Colleges of Agriculture $(8 \%, n=44)$ and Engineering $(9 \%, n=51)$ to $28 \%(n=68)$ for the College of Health and Human Sciences. The response rates for the remaining colleges ranged from $12 \%$ to $20 \%$. In comparison, response rates for other surveys of faculty reported recently in the literature ranged from 15\% to 52\% (Bury 2011; National Study; Shannon and Bradshaw 2002; Cook, et al., 2000; Park and Denson 2009; Briggs and Pehrsson 2010).

\section{Demographics of Respondents.}

Most of the respondents were tenured Associate or Full Professors ( $n=118,66 \%)$ or held tenure-track Assistant Professor positions $(n=49,28 \%)$. Six percent of the respondents $(n=10)$ 
were clinical/research faculty (non-tenured) or visiting faculty (Assistant, Associate, Professor). None of the respondents were Emeritus Faculty. The percentage of tenured and visiting faculty who responded to the survey corresponded proportionally to the percentage of faculty in those categories employed at Purdue.

Fifty-six percent $(\mathrm{n}=171)$ of the respondents taught from 1-7 years both at the postsecondary level and at Purdue. Three of the respondents provided data that may have been inaccurate: the total number of years teaching in postsecondary education was from 1-7 while the number of years teaching at Purdue was greater than 8 . Smaller percentages of individuals had comparable experience in the categories of 8-15 and greater than 15 years, but those represented the agreement between total postsecondary education and time at Purdue.

Seventy-five percent $(\mathrm{n}=225)$ of the total respondents taught undergraduate students. Eighty-two percent of the respondents $(n=184)$ who taught undergraduates required the students to write a paper or give a presentation.

\section{How Students Learned to Define a Topic.}

Respondents were asked how the undergraduate students in any of their courses learned to define a topic for a course project. This corresponded to the information literacy competency, "determine the nature and extent of information needed." The survey question explained that this meant that the faculty member gave the students broad parameters about a general subject area for a course project, but required the students to identify a specific topic. Respondents could check all options that applied. Table 3 shows the ways that respondents indicated that undergraduate students learned this by College/School. There were statistically significant differences associated with the schools and the total number of responses for the statistically significant categories was 251 . 
The most common way that undergraduate students learned to define a topic for a course project was by the faculty member providing the instruction $(n=132,53 \%)$. This was done through lectures, handouts, and/or links to online sources. Thirty-five percent $(n=89)$ of the respondents assigned a project topic to the students. Twelve percent $(n=30)$ indicated that the faculty member expected students to know how to define a topic for a course project before the students took their course.

[Insert Table 3]

\section{How Students Learned to Find Resources For Their Courses.}

Respondents were asked how the undergraduate students in any of their courses learned to effectively and efficiently find journal articles or books for their courses, other than those the faculty member assigned. This corresponded to the information literacy competency, "access the needed information effectively and efficiently." Respondents could check all options that applied. The only statistically significant responses, showing differences between the schools, were that the faculty member provided the instruction $(n=114,57 \%)$ and the faculty expected the students to know this before they took their courses $(n=87,43 \%)$. Table 4 shows the percentage of these responses by College/School. Engineering $(n=25)$ had the largest number of faculty providing this instruction themselves. Management $(n=3)$ and Education $(n=4)$ were least likely to provide this instruction themselves. Management $(n=6)$ and Education $(n=5)$ were also the least likely to expect students to know this before the students took a course. [Insert Table 4]

An analysis examined College/School differences in faculty-librarian collaboration on teaching students to find journal article or books for their courses, other than those the faculty member assigned. This is a facet of information literacy competency that librarians typically teach. However, the relationship was not statistically significant. 


\section{How Students Learned to Evaluate Resources For Their Courses.}

Respondents were asked how the undergraduate students in any of their courses learned to critically evaluate journal articles or books for their courses, other than those they assigned. This corresponded to the information literacy competency, "evaluate information and its sources critically." Respondents could check all options that applied. Table 5 shows that Liberal Arts $(\mathrm{n}=22)$ and Engineering $(\mathrm{n}=21)$ had the most faculty providing this instruction themselves. Agriculture faculty $(n=1)$ were least likely to provide this instruction themselves. [Insert Table 5]

The faculty with more teaching experience tended to teach critical evaluation themselves. Fifty-four percent of the faculty who taught critical evaluation themselves had 8-15 years of teaching experience. Forty-seven percent of the faculty who taught critical evaluation themselves had more than 15 years of teaching experience. Fourteen percent $(n=25)$ of the individuals with less than 8 years of experience taught critical evaluation themselves.

There were differences between the Colleges when examining the relationship between the percentage of faculty who taught critical evaluation in individual Colleges. Figure 1 shows that Agriculture $(n=1,2 \%)$ and Health $(n=10,14 \%)$ had the lowest percentage of Agriculture and Health faculty who taught this. The highest percentage was in Liberal Arts $(\mathrm{n}=22,76 \%)$. The remaining Colleges ranged from 23\% to 41\% (Management,

$\begin{array}{lr}\text { Ag } & 2 \% \\ \text { Health } & 14 \% \\ \text { Mgt } & 23 \% \\ \text { Educ } & 31 \%\end{array}$




$\begin{array}{ll}\text { Sci } & 33 \% \\ \text { Engr } & 40 \% \\ \text { Tech } & 41 \% \\ \text { Lib Arts } & 76 \%\end{array}$

[insert Figure 1]

\section{How Students Learned to Synthesize Information.}

Respondents were asked how the undergraduate students in any of their courses learned to synthesize information into papers and presentations. This corresponded with the information literacy competency, "use information effectively to accomplish a specific purpose." Respondents could check all options that applied. Table 6 shows that Liberal Arts $(n=24)$ and Engineering $(n=23)$ had the most faculty providing this instruction themselves. Respondents from Education $(n=3)$ and Management $(n=5)$ were least likely to provide this instruction themselves.

[Insert Table 6]

\section{How Students Learned about Avoiding Plagiarism.}

Respondents were asked how the undergraduate students in any of their courses learned about avoiding plagiarism. This corresponded to the information literacy competency, "access and use information ethically and legally." Table 7 shows the statistically significant ways that respondents indicated that undergraduate students learned this: by the faculty member providing the instruction $(\mathrm{n}=129,54 \%)$ and by expecting students to know this before taking courses $(\mathrm{n}=109,46 \%)$.

[Insert Table 7] 
Liberal Arts $(n=26)$ and Engineering $(n=24)$ had the most faculty providing this instruction themselves. Faculty in Education $(n=3)$ and Management $(n=9)$ were least likely to provide this instruction themselves. Forty-six percent $(\mathrm{n}=109)$ of the respondents indicated that they expected students to know this before they took their course. Agriculture $(n=20)$ and Liberal Arts ( $n=20)$ were most likely to expect this. Education $(n=6)$ and Management $(n=7)$ were least likely to expect this.

A cross tabulation examined whether there were differences between the Colleges in the expectation of the faculty that students know each of the information literacy competencies before they took courses. This analysis indicated that avoiding plagiarism was the only information literacy competency that was statistically different. Table 8 shows the distribution of those responses.

[Insert Table 8]

The Colleges showed three different response patterns:

- Responses from Agriculture and Education to the question of whether the faculty members expected the students to know how to avoid plagiarism before taking their courses were approximately equal ( $44.4 \%$ and $46.2 \%$, respectively).

- Liberal Arts was the only College in which substantially more respondents $(69 \%=y e s ;$ $31 \%=$ no) indicated that they expected students to know how to avoid plagiarism before students took their courses.

- The remaining Colleges showed a larger percentage of respondents indicating that they did not expect students to know how to avoid plagiarism before students took their courses.

Two of the comments by respondents related to plagiarism were: 
- Plagiarism is emphasized in the handout and in class; and the penalties are severe.

- We use electronic submission...to run a plagiarism check.

\section{DISCUSSION.}

This survey examined the extent to which teaching information literacy concepts to undergraduate students occurs at Purdue from the perspective of the disciplinary faculty. Because the overall response rate for the initial survey was $12 \%$, the results cannot be generalized conclusively. But these results provide a new campus-wide perspective on information literacy that can form a foundation for future studies.

The majority of the respondents taught undergraduate students (75\%) and the majority of those required the students to write a paper or give a presentation (82\%). This confirms that information literacy competencies are important for student success at this research university.

\section{Who Teaches Information Literacy.}

The results strongly indicate that the faculty themselves provided instruction in defining topics; finding articles and books for projects; critically evaluating resources; synthesizing materials; and avoiding plagiarism. In general, the faculty did not assign teaching assistants, collaborate with librarians, or engage other staff at the University to teach these competencies. This finding is in agreement with other studies (Bury 2011, p. 55; McGuinness 2006, p. 575).

\section{Collaboration.}

Respondents who had taught in postsecondary institutions for more than 7 years tended to teach information literacy competencies themselves. It is possible that faculty who do not have tenure might be reluctant to allow others to provide instruction because of fears about the possibility of negatively affecting course evaluations. Other studies indicate that "faculty generally teach the 
same way they were taught as students, more so when they are more concerned with achieving tenure and promotion through their research productivity" (Boice 1992, 2000). If they did not experience collaborative instruction as students, then they may not be likely to involve others in their teaching. The discipline, type of institution, and organizational culture may influence the ways in which faculty collaborate and the extent to which they collaborate (Eddy 2010, p. 55; McGuinness 2006, p. 575).

It is also possible that non-tenured faculty might not be aware of other resources in the University to help them provide this instruction. Experienced faculty may have developed effective strategies for teaching information literacy. However, teaching assistants could greatly benefit from learning to teach these competencies, since they are preparing to be future faculty. Faculty in the libraries and other university staff, such as writing centers and copyright offices, have expertise in these competencies that could enhance instruction provided by the faculty. The Purdue Libraries information literacy program and an information literacy tutorial first developed in 1997 have a substantial reputation (Seamans 2012, p. 243; Sullivan 2004, p. 82-83; S. Weiner, et al. 2012). Increased efforts to communicate this on campus may result in more collaboration with librarians. Further investigation should be done to better understand the faculty perspective on this question.

\section{Information Literacy Competency as Pre-Requisite.}

To a lesser extent, the survey respondents expected the students to know how to avoid plagiarism, find articles and books, and define topics for their projects before they took courses. This implies that curricula should be planned so that students have instruction and demonstrate competence in these areas before they take courses in which there is the expectation that they know them. Assessment of students' mastery of the competencies should occur. 
Information Literacy

\section{Disciplinary Differences.}

There were differences in the Colleges/Schools in providing instruction in critical evaluation. Figure 1 shows that within individual Colleges, less than $20 \%$ of faculty in Agriculture $(n=1,2 \%)$ and Health $(n=10,14 \%)$ provided instruction themselves. Liberal Arts $(n=22,76 \%)$ had the highest percentage. In the remaining Colleges, from $23 \%-41 \%$ of the faculty provided this instruction (Management, $n=5,23 \%$; Education, $n=4,31 \%$; Science, $n=14$, $33 \%$; Engineering, $n=21,41 \%$, Technology, $n=12,41 \%$ ). This is an area that needs further exploration to determine why there are differences in the Colleges/Schools. Specific colleges may emphasize different competencies as appropriate to their programs. Critical evaluation is commonly cited in studies about the competencies that people in the workforce need to have. It is important to understand whether there is sufficient instruction in this area to prepare students for success in their careers.

There were also differences among the Colleges/Schools in providing instruction about avoiding plagiarism. Figure 2 shows that Education $(n=3,23 \%)$ and Health and Human Sciences $(n=18,25 \%)$ faculty provided the least instruction in this area. Agriculture $(n=14,31 \%)$, Management $(n=9,41 \%)$ Science $(n=17,41 \%)$, and Engineering $(n=24,46 \%)$ faculty provided a moderate amount. Technology (62\%) and Liberal Arts (90\%) faculty provided the most instruction in avoiding plagiarism. This should be explored further because plagiarism is a major issue on college campuses. One question to be explored is whether the Colleges/Schools in which more faculty provide instruction themselves in plagiarism have a lower incidence of it.

\section{Differences by Number of Years Teaching.}

Newer faculty were less likely to teach critical evaluation. This might not be an expectation in the courses they teach, or they may need help in teaching it. Tenured faculty 
tended to provide instruction in defining a topic; finding articles and books; and synthesizing information. Non-tenured faculty tended to teach students to avoid plagiarism. The reasons for this difference should be investigated. Why do faculty who have been teaching longer not provide instruction on avoiding plagiarism, while newer faculty and those who do not have tenure do? And why do newer faculty and those who do not have tenure tend not to teach the other information literacy competencies?

\section{CONCLUSION.}

This paper described the results of a survey of faculty conducted to understand the extent to which teaching information literacy concepts to undergraduate students occurred in a large research university. The results indicated that faculty taught the information literacy competencies themselves or expected the students to have these competencies when they took the respondents' courses. They generally did not collaborate with others on campus to teach these competencies. Future studies might consider the students' perspectives on how they learn information literacy competencies; why course faculty tend not to use other campus resources to provide instruction in these competencies; and how graduate students learn information literacy competencies. 


\section{References.}

About NSSE. 2012. http://nsse.iub.edu/html/about.cfm. Accessed June 26, 2012.

Allner, I. B. 2010. Teaching of information literacy: Collaboration between teaching faculty and librarians. M.A. thesis, Texas A\&M University-Kingsville.

ACRL. 2000. Information literacy competency standards for higher education. http://www.ala.org/ala/mgrps/divs/acrl/standards/informationliteracycompetency.cfm\#sta n. Accessed June 26, 2012.

Barratt, C., K. Nielsen., C. Desmet, and R. Balthazor. 2009. Collaboration is key: Librarians and composition instructors analyze student research and writing. portal: Libraries and the Academy 9(1): 37-56.

Bloom, B. S., ed. 1956. Taxonomy of educational objectives: The classification of educational goals. In Handbook I: Cognitive domain. New York: David McKay.

Boice, R. 1992. The new faculty member: Supporting and fostering professional development. San Francisco, CA: Jossey-Bass.

Boice, R. 2000. Advice for new faculty. Boston, MA: Allyn \& Bacon.

Breivik, P. S. 2004. Foreward. In Integrating Information Literacy into the Higher Education Curriculum: Practical models for transformation, ed. Ilene F. Rockman and Associates, xi-xiv. San Francisco: Jossey-Bass.

Briggs, C. A. and D. Pehrsson. 2010. Gender differences in research mentorship and pretenured counselor educators. Journal of Women in Educational Leadership 8(1): 3-18.

Bundy, A. (ed.) 2004. Australian and New Zealand information literacy framework principles, standards and practice. $2^{\text {nd }}$ ed. Adelaide: Australian and New Zealand Institute for 
Information Literacy. http://www.library.unisa.edu.au/learn/infolit/Infolit-2ndedition.pdf. Accessed June 26, 2012.

Bury, S. 2011. Faculty attitudes, perceptions and experiences of information literacy: A study across multiple disciplines at York University, Canada. Journal of Information Literacy 5(1). http://ojs.lboro.ac.uk/ojs/index.php/JIL/article/view/PRA-V5-I1-2011-1. Accessed June 26, 2012.

Caravello, P. S., E. L. Kain, and T. Kuchi. 2008. Information literacy: The partnership of sociology faculty and social science librarians. Teaching Sociology 36(1): 8-16.

College learning for the new global century: A report from the National Leadership Council for Liberal Education \& America's Promise. 2007. Washington, DC: American Association of Colleges and Universities. http://www.aacu.org/leap/documents/GlobalCentury_final.pdf. Accessed June 26, 2012.

Cook, C., F. Heath, and R. Thomson. 2000. A meta-analysis of response rates in Web- or Internet-based surveys. Educational and Psychological Measurement, 60(6): 821-26.

Dobozy, E. and J. Gross. 2010. Pushing library information to first-year students: An exploratory of faculty/library collaboration. Australian Academic \& Research Libraries 41(2): 90-99.

Dugan, M. 2008. Embedded librarians in an ag econ class: Transcending the traditional. Journal of Agricultural \& Food Information 9(4): 301-9.

Eddy, P. L. 2010. Partnerships and collaborations in higher education. ASHE Higher Education Report 36(2):1-115.

Elrod, S. L. and M. M. Somerville. 2007. Literature-based scientific learning: A collaboration model. Journal of Academic Librarianship 33(6):684-91. 
Floyd, D. M., G. Colvin, and Y. Bodur. 2008. A faculty-librarian collaboration for developing information literacy skills among preservice teachers. Teaching and Teacher Education 24: $368-76$.

Garner, S. D. 2006. High-Level Colloquium on Information Literacy and Lifelong Learning Bibliotheca Alexandrina, Alexandria, Egypt, November 6-9, 2005: Report of a meeting sponsored by the United Nations Education, Scientific, and Cultural Organisation (UNESCO), National Forum on Information Literacy (NFIL) and the International Federation of Library Associations and Institutions (IFLA). http://www.ifla.org/publications/high-level-colloquium-on-information-literacy-andlifelong-learning. Accessed June 26, 2012.

Garritano, J. R. and F. B. Culp. 2010. Chemical information instruction in academe: Who is leading the charge? Journal of Chemical Education 87(3): 340-343.

Gullikson, S. 2006. Faculty perceptions of ACRL's information literacy competency standards for higher education. Journal of Academic Librarianship 32(6): 583-92.

Irving, C. and J. Crawford. 2008. A national information literacy framework: Scotland. http://caledonianblogs.net/nilfs/files/2009/03/draft-information-literacy-framework1h.pdf. Accessed June 26, 2012.

Johnson, O. J., J. S. Whitfield, and B. Grohe. 2011. Improving social work students' information literacy skills: A faculty and librarian collaboration. Journal on Excellence in College Teaching 22(3): 5-21.

Kaplowitz, J. 2005. Faculty focus groups: UCLA information literacy initiative. UC Los Angeles: UCLA Library. http://escholarship.org/uc/item/83d6v8fg. Accessed June 26, 2012. 
Kobzina, N. G. 2010. A faculty-librarian partnership: A unique opportunity for course integration. Journal of Library Administration 50: 293-314.

Madray, A. 2008. The anatomy of a plagiarism initiative: One library's campus collaboration. Public Services Quarterly 4(2): 111-125.

McGinness, C. 2006. What faculty think-Exploring the barriers to information literacy development in undergraduate education. Journal of Academic Librarianship 12(6): $573-582$.

National Study of Postsecondary Faculty: Design. National Center for Education Statistics Institute of Education Sciences . http://nces.ed.gov/surveys/nsopf/design.asp. Accessed June 26, 2012.

Shannon, D.M., and C. C. Bradshaw. 2002. A comparison of response rate, response time, and costs of mail and electronic surveys. Journal of Experimental Education, 70(2): 179-92.

Park, J. J., and N. Denson. 2009. Attitudes and advocacy: Understanding faculty views on racial/ethnic diversity. Journal of Higher Education 80(4): 415-38.

Saunders, L. (2007). Regional accreditation organizations' treatment of information literacy: Definitions, collaboration, and assessment. Journal of Academic Librarianship 33(3): $317-326$.

Seamans, N. H. (2012). Information literacy reality check. In Transforming information literacy programs: Intersecting frontiers of self, library culture, and campus community, ed. C. W. Wilkinson and C. Bruch, 221-44. Chicago, IL: Association of College and Research Libraries.

SCONUL Working Group on Information Literacy. 2011. The SCONUL seven pillars of information literacy: Core model for higher education. London: Society of College, 
National and University Libraries.

http://www.sconul.ac.uk/groups/information_literacy/publications/coremodel.pdf. Accessed June 26, 2012.

Supplemental Academic Libraries Survey (ALS) 2010 Tables to NCES 2012-365. Washington, DC: Institute of Education Sciences, National Center for Education Statistics. http://nces.ed.gov/pubs2012/2012365_1.pdf. Accessed June 26, 2012.

Sullivan, P. 2004. Developing freshman-level tutorials to promote information literacy. In Information literacy meeting of experts, Prague, the Czech Republic, September 20-23, 2003: Report of a meeting sponsored by the US National Commission on Libraries and Information Science (NCLIS) and the National Forum on Information Literacy (NFIL) with the support of the United Nations Education, Scientific, and Cultural Organization (UNESCO), ed. S. Thompson. http://portal.unesco.org/ci/en/ev.phpURL_ID=19634\&URL_DO=DO_TOPIC\&URL_SECTION=201.html. Accessed June 26, 2012.

Walter, S. 2007. Using cultural perspectives to foster information literacy across the curriculum. In Proven strategies for building an information literacy program, S. C. Curzon and L. D. Lampert, eds., 55-75. New York: Neal-Schuman Publishers, Inc.

Wang, L. 2011. An information literacy integration model and its application in higher education. Reference Services Review 39(4): 703-720.

Weiner, J. 2011. Is there a difference between critical thinking and information literacy? A systematic review 2000-2009. Journal of Information Literacy 5(2): 81-92. http://ojs.lboro.ac.uk/ojs/index.php/JIL/article/view/LLC-V5-I2-2011-2/1575 
Information Literacy

Weiner, S. 2011. How information literacy becomes policy: An analysis using the Multiple Streams Framework. Library Trends 60(2): 297-311.

Weiner, S., N. Pelaez, K. Chang, and J. Weiner. 2012. Biology and nursing students' perceptions of a web-based information literacy tutorial. Communications in Information Literacy 5(2): 187-201.

Willison, J. W. 2012. When academic integrate research skill development in the curriculum. Higher Education Research \& Development forthcoming: 1-15.

Wu, D. Y., and S. L. Kendall. 2006. Teaching faculty's perspectives on business information literacy. Reference Services Review 34(1): 86-96. 
Information Literacy

\section{Appendix 1. Survey on Integration of Information Literacy in Purdue Courses}

Dear member of the College/School of ___ Faculty,

Please take a few minutes to respond to an important survey about how your students learn about information literacy concepts through courses. Information literacy is the ability to:

- Determine the nature and extent of information needed

- Access the needed information effectively and efficiently

- Evaluate information and its sources critically

- Use information effectively to accomplish a specific purpose

- Understand the economic, legal, and social issues surrounding the use of information

- Access and use information ethically and legally (http://www.ala.org/ala/mgrps/divs/acrl/standards/informationliteracycompetency.cfm\#st an)

This 10-question survey is designed to be answered in less than 5 minutes. The results are important to all of us in developing effective support to faculty by the Purdue Libraries to enhance information literacy skills. A report of the findings will be submitted for publication. This study has been approved by the Purdue IRB.

We very much appreciate your participation! Please feel free to contact us if you have any questions. 
Information Literacy

Sharon Weiner, EdD

Professor and W. Wayne Booker Chair in Information Literacy

Purdue Libraries

Beth McNeil, MLS

Associate Dean for Academic Affairs

Purdue Libraries

The purpose of this survey is to determine how students learn about information literacy concepts through courses at Purdue University. Academia, industry, and government recognize the importance of information literacy. The W. Wayne Booker Chair in Information Literacy was established at Purdue to help ensure that our graduates are prepared to meet the challenges of global competition in science and industry.

According to the Association of College and Research Libraries, the information literate student can:

- Determine the nature and extent of information needed

- Access the needed information effectively and efficiently

- Evaluate information and its sources critically

- Use information effectively to accomplish a specific purpose 
Information Literacy

- Understand many of the economic, legal, and social issues surrounding the use of information

- Access and use information ethically and legally (http://www.ala.org/ala/mgrps/divs/acrl/standards/informationliteracycompetency.cfm\#st an)

The results of this survey are important to all of us in developing effective support to faculty by the Purdue Libraries to enhance information literacy skills. A report of the findings will be submitted for publication.

This survey is designed to be answered in less than 5 minutes. We very much appreciate your participation!

\section{Do you teach undergraduate students?}

_ Yes (continue survey)

_ No (go to "Thank you for participating" page)

\section{Do you require students to prepare papers or presentations for any of your} undergraduate classes?

_Yes (continue survey)

_ No (go to "Thank you for participating" page) 
3. How do the undergraduate students in any of your courses learn to define a topic for a course project? This means that you may give students broad parameters about a general subject area, but they must identify a specific topic for their project. (Check all that apply.)

_I provide the instruction (lectures, handouts, links to online sources (provide a text box:

"Comment")

_.My teaching assistant teaches them

_A librarian collaborates with me on teaching them

_Other Purdue faculty or staff teach them

__ I expect them to know this before they take my courses

__ I assign a project topic

4. How do the undergraduate students in any of your courses learn to effectively and efficiently find journal articles or books for your courses, other than those you have assigned? (Check all that apply.)

__ I provide the instruction (lectures, handouts, links to online sources (provide a text box:

“Comment")

_My teaching assistant teaches them

_A librarian collaborates with me on teaching them

_-Other Purdue faculty or staff teach them

_ I expect them to know this before they take my courses 


\section{How do the undergraduate students in any of your courses learn to critically evaluate} journal articles or books for your courses, other than those you have assigned? (Check all that apply.)

_I provide the instruction (lectures, handouts, links to online sources (provide a text box:

"Comment")

_.My teaching assistant teaches them

_A librarian collaborates with me on teaching them

_ Other Purdue faculty or staff teach them

__ I expect them to know this before they take my courses

\section{How do the undergraduate students in any of your courses learn to synthesize} information into papers and presentations? (Check all that apply.)

__ I provide the instruction (lectures, handouts, links to online sources (provide a text box:

"Comment")

_ My teaching assistant teaches them

_A librarian collaborates with me on teaching them

_ Other Purdue faculty or staff teach them

__ I expect them to know this before they take my courses

__ expect them to learn on their own 
7. How do undergraduate students in any of your courses learn about avoiding plagiarism (Check all that apply.)

_I provide the instruction (lectures, handouts, links to online sources (provide a text box: “Comment")

__ My teaching assistant teaches them

_A librarian collaborates with me on teaching them

_Other Purdue faculty or staff teach them

_ I expect them to know this before they take my courses

_ I expect them to learn on their own

8. Do you have any additional comments about information literacy instruction in your courses? (provide a text box: "Comment")

Demographics. These questions request information about your status and experience in teaching.

9. What type of appointment do you have at Purdue?

_Clinical \& Research Faculty (non-tenured)

_ Tenured Faculty (Associate, Professor)

_ Tenure-track Faculty (Assistant) 
Information Literacy

_ Visiting Faculty (Assistant, Associate, Professor)

_Emeritus Faculty

10. How many years of experience do you have teaching at postsecondary level?

11. For how many years have you been a faculty member at Purdue?

12. If you would like to discuss information literacy further, you may contact the CoDirectors of this project:

Sharon Weiner, Professor and W. Wayne Booker Chair in Information Literacy 765-496-3128

sweiner@purdue.edu

Beth McNeil, Professor and Association Dean for Academic Affairs

$765-496-2261$

memcneil@purdue.edu

“Thank you for participating” Page.

Thank you for participating in this survey! 